J. Appl. Cryst. (1974). 7, 191

\title{
Orientation des Faces Limites et Epaisseur des Lamelles dans les Echantillons de Polyamides à Texture d'Orientation Unique
}

\author{
Par Jean-Jacques Point et Annie Goffin \\ Université de Mons, Place Warocqué 17, 7000-Mons, Belgique
}

\begin{abstract}
Deux types d'échantillons permettent la mesure de l'orientation des faces limites des lamelles et du rapport $R$ de la longueur des plis à celle des monomères. Keller, Dreyfuss et leurs collaborateurs ont fait des mesures sur les polyamides cristallisées à partir de solutions. Dans cette communication, on examine si les résultats obtenus sont aussi applicables aux échantillons cristallisés en masse et orientés de façon à obtenir une texture d'orientation unique. Pour les polyamides que nous avons étudiés $(6,6 ; 6,8$; $6,10 ; 6,12 ; 6,9 ; 6 ; 8 ; 12$ et 11$)$ les rapports $R$ de la longueur des plis à celle des monomères ont des valeurs similaires pour les deux types d'échantillons. Cependant dans le cas des polyamides 6,$6 ; 6,8 ; 6,10$ et 6,12 ce rapport (qui vaut 4 pour les cristaux préparés à partir de solutions) est compris entre 5 et 4 pour les échantillons orientés. Il diminue de façon monotone quand la longueur du monomère croît. $R$ diminue aussi légèrement lors d'un recuit thermique. Ces observations ont discutées. Pour mesurer de façon précise l'orientation de l'axe des diagrammes de diffraction de rayons $\mathrm{X}$ aux petits angles dans le réseau réciproque du cristal on a réussi à préparer des échantillons à texture d'orientation presque unique c'est-à-dire dans lesquels presque tous les cristaux ont la même orientation. Dans le cas des polyamides 6,$6 ; 6,8 ; 6,10 ; 6,12 ; 6,9$ et 11 , l'axe du diagramme de diffraction de rayons $\mathrm{X}$ aux petits angles et la normale des plans (001) font un angle pouvant atteindre $10^{\circ}$. L'écart observé est dans le sens prévu d'après ce qu'on connait de la déformation plastique des cristaux et diminue lors d'un recuit thermique. On note enfin que dans le cas de polyamides 6,6 et 6,10 la transition conduisant à la texture d'orientation unique est le plus aisément compréhensible si le plan des plis est aussi celui des feuillets contenant les liaisons $\mathrm{H}$. En conclusion, dans les échantillons à texture unique de ces polyamides les lamelles ont approximativement la même épaisseur et la même orientation par rapport à la maille que les cristaux plus parfaits préparés à partir de solutions. Le cas des échantillons de nylon 8 est particulier; les échantillons se composent de deux phases, une phase pseudohexagonale et une phase monoclinique (non décrite dans la littérature). L'axe du diagramme de diffraction de rayons $X$ aux petits angles est normal au plan (001) de cette phase monoclinique. Cet axe devient parallèle à l'axe des chaînes lors de la transition de phase monoclinique pseudohexagonal. Ce dernier résultat confirme nos travaux antérieurs indiquant que le diagramme de diffraction de rayons $X$ aux petits angles peut être représentatif non pas de la structure de la totalité de l'échantillon mais seulement de celle d'une phase mineure; Des résultats préliminaires concernant d'autres systèmes sont discutés.
\end{abstract}

J. Appl. Cryst. (1974). 7, 191

\section{Small-Angle X-ray Scattering from a Dilute Solution of the Polystyrene/Polybutadiene/Polystyrene Block Copolymer in Methyl Ethyl Ketone}

\author{
By J. Baldrian and J. Pleštil \\ Institute of the Macromolecular Chemistry, Czechoslovak Academy of Sciences, 16206 Prague 6, \\ Czechoslovakia
}

The small-angle X-ray scattering from a dilute solution of the polystyrene/polybutadiene/polystyrene block copolymer in methyl ethyl ketone was measured. The molecular weight averages of the copolymer were $M_{n}=1.12 \times 10^{5}, M_{W}=1.4 \times 10^{5}$, the styrene/butadiene weight ratio was $51 / 49$ and the ratio of butadiene isomers 1.4 and 1.2 was $42 / 7$. Since methyl ethyl ketone is a selective solvent for polystyrene, the block copolymer formed micelles in solution. The small-angle diffraction curves were used to determine the radius of gyration of the micelles $(250 \AA)$; their weight determined from absolute measurements of diffracted intensity was $37 \times 10^{6}$. The micelles are unstable in the presence of air. An idealized model of micelle represented by a sphere with a polybutadiene nucleus and polystyrene shell allowed the estimation of the radius of the polybutadiene core $(200 \AA)$ and of the whole micelle ( $350 \AA)$. 